\title{
Bioremediation of Oil-Contaminated Soils of South Kazakhstan
}

\author{
Akmaral Issayeva $^{1}$, Aigul Uspabayeva ${ }^{1}$, Valikhan Bishimbayev ${ }^{1}$, Erzhan Issayev $^{1}$ \& Aigul Sattarova ${ }^{1}$ \\ ${ }^{1}$ M. Auezov South Kazakhstan State University, Shymkent, Kazakhstan \\ Correspondence: Akmaral Issayeva, M. Auezov South Kazakhstan State University, Shymkent, Republic of \\ Kazakhstan. Tel: 77-701-324-5044. E-mail: akissayeva@mail.ru
}

Received: December 3, $2014 \quad$ Accepted: December 16, $2014 \quad$ Online Published: April 25, 2015
$\begin{aligned} & \text { doi:10.5539/mas.v9n6p97 } \\ & \text { URL: http://dx.doi.org/10.5539/mas.v9n6p97 }\end{aligned}$

The research is financed by Grant of the Ministry of Education and Science on the project: "Production of biological products of a broad spectrum of activity"(2011-2014).

\begin{abstract}
In a weakly or moderately polluted with oil (0.3-1.0\%) the total number of soil microorganisms, including hydrocarbon-oxidizing, you can improve cultural practices (tillage, irrigation, fertilization) without making out of hydrocarbon-oxidizing microorganisms (HOM). In the arid zone is more expedient to begin bioremediation of oil-contaminated areas of work for the fall, to use autumn and spring soil moisture for mineralization activity of microorganisms.
\end{abstract}

Keywords: bioremediation, oil-contaminated soils; hydrocarbon-oxidizing microorganisms

\section{Introduction}

Environmental protection from oil pollution gains special sharpness due to the lack of cheap methods of cleaning. Decomposition of oil products in the soil under natural conditions - biogeochemical process in which the main role is played by the soil microorganisms mineralizing oil to carbon dioxide and water. Using their catabolic activity, it is possible to accelerate processes of self-restoration of the broken ecosystem considerably. As is shown in papers of Jiang C, et al. (2001) and Marn S, Khodijah T. (2004), recently, biological remediation methods have been successfully used for solving of soil treatment problem. These methods are based on activation of microbiological destruction of oil and oil products. Among them: a stimulation of indigenous microflora growth, by means of arranging of optimal conditions for its development (Wyszkowska $J$ and Kucharski J, 2000, Panicker G et al., 2002) and an introduction or augmentation of active hydrocarbon-oxidizing microorganism cultures in the soil or water bodies together with a number of biogenic elements in the form of biopreparations (Dzongo-Gadet M. et al., 2005, Ayotamuno, 2009, Keil et al., 2011). These methods are advantageous due to high efficiency and mild influence, which does not upset the balance of soil ecosystem.

\section{Material and Methods of Research}

Soil. Soil samples were collected from Refinery Limited Liability Company 'PetroKazahstan Oil Products' ('PKOP' LLP). Soil samples were used to analyze the physic-chemical parameters and to isolate the bacteria. Typical medium loamy soil-gray soils with different oil content. Selected oil contaminated soil and control the main parameters did not differ among them. The content of humus in these soils is $1.6-1.8 \%$, total nitrogen $\mathrm{N}$ (Kjeldahl) $0.146 \%$, the mobile P2O5 $38 \mathrm{mg} / \mathrm{kg}$ soil.

Collection of Samples: Samples were collected at a depth within $5 \mathrm{~cm}$ from the surface of the soil. They were collected in sterile polythene bags and tightly packed. They were then carefully transferred to the laboratory for analysis and stored at $4^{\circ} \mathrm{C}$ aseptically before processing.

Physic-Chemical Properties of Contaminated Soil: The soil physic-chemical parameters were analyzed. Particle size analysis was carried out using the hydrometer method (Bouyocos, G. H., 1951). Soil texture was sandy loam. Soil $\mathrm{pH}$ was determined using a $\mathrm{pH}$ meter. The temperature of the soil samples was determined using a mercury thermometer. The electrical conductivity of the soil suspension was measured using the electronic digital conductivity meter. Total nitrogen was determined by Kieldal digestion and steam distillation method (Sankaram, A., 1996). Available phosphorous was determined by the method of Available micro nutrients were determined by the method of Olsen, S. R.et al. (1954). 
Oil and diesel fuel. Oil Kumkol field, which is characterized by the following indicators: pour point 100C, silica gel resin content of $19.2 \%$; carbo-karboides $5.82 \%$; $5.4 \%$ asphaltenes; wax $7.5 \%$; $0.064 \%$ sulfur. At a temperature of $200 \mathrm{C}$ has a density $-0.850 \mathrm{~g} / \mathrm{cm} 3$. Fractions low sulfur diesel fuel, acidity does not exceed $3 \%$. At a temperature of $200 \mathrm{C}$ has a density $-0.804 \mathrm{~g} / \mathrm{cm} 3$. The high content of n-alkanes (24\%).

Microbiological survey of oil-contaminated areas has been performed in accordance with techniques generally accepted in microbiolocigal practice (Lazar et al., 1999, Margesin et al., 2000, Mishra et al., 2001, Kaplan CW and Kitts CL, 2004). Soil microorganisms have been separated in peptone agar medium, using Koch's method . Oil products of different fractions have been used as for carbon nutrition of microorganisms (Wan N et al., 2002, Larter SR et al., 2008).

Isolation and Enumeration of Bacteria: Isolation and enumeration of bacteria were performed by soil dilution plate technique using mineral salts agar media. One gram of dried soil was dissolved in $9 \mathrm{ml}$ of distilled water and agitated vigorously. Different aqueous dilutions, 10, 10, 10 of the suspension were applied on to plates and $20 \mathrm{ml}$ of melted medium at around $50^{\circ} \mathrm{C}$ was added to it. After gently rotating, the plates were incubated at $37^{\circ} \mathrm{C}$ for 24 hours. Enumeration of different isolates was carried out. Selected colonies of bacteria were transferred from mixed culture of the plates on to respective agar plates and incubated at $37^{\circ} \mathrm{C}$ for 24 hours. Plates containing pure cultures were stored at $4^{\circ} \mathrm{C}$ until for the examinations.

Characterization of Isolates: Each isolate was examined many times for its size, shape, margin, consistency opacity, elevation, pigmentation, Gram reaction and cell morphology as described by Holt et al (1994). Diagnostic properties used include motility, production of catalase, indole, urease, oxidative fermentation of sugars, methyl red test, vogues proskauer test and citrate utilization test.

Biogenic additives. Under field conditions, the nitrogen and phosphorus were added as a $1 \%$ aqueous solution of monoammonium phosphate.

Remediation technique. Oily soil remediation technique included the following main activities: loosening (aeration) to a depth of 35-40 cm using a plow attached to a wheel tractor in tight spaces - manually. Microbial biomass were made by spraying a solution. Repeated loosening the soil was carried out at least once in 10 days, the next day after watering. Cleaned of soil moisture was maintained at $50-60 \%$ of its full capacity. Sawdust was added in an amount of 2-10 $t$ / ha depending on the type and extent of oil pollution.

Pilot tests. For tests in real industrial conditions the sites which are exposed to regular and single oil spills were chosen, each territory was characterized by pollution by a certain oil product: a site $1-$ oil $(0,3-0,5 \%), 2$ - oil $(0,7-1,0 \%), 3$ - diesel fuel $(2,0-2,5 \%), 4$ - fuel oil $(1,0-2,3 \%), 5$ - fuel oil (more than $10 \%), 6$ - slime $(9,8-14,0 \%)$. Pilot tests were carried out under real production conditions in local areas of 'PKOP' LLP.

\section{Research Results}

Pollution of the soil oil is to selective factors under the influence of which the biocenosis with limited structure of the dominating groups of microorganisms is formed. As a result of microbiological inspection it was revealed that as a result of chronic toxic influence of oil the structure of microflora on the surveyed site is rather uniform, and is presented by such sorts, as Pseudomonas, Micrococcus and a number of gram-positive rhabdoid bacteria. It was established that after emergency oil spills sharp decrease in number of heterotrophes was observed, however in a month after pollution the caption of natural microflora raises that is probable, connected with end of the period of adaptation of a soil microbiota to changed to physical and chemical conditions of the environment (Figure 1). 


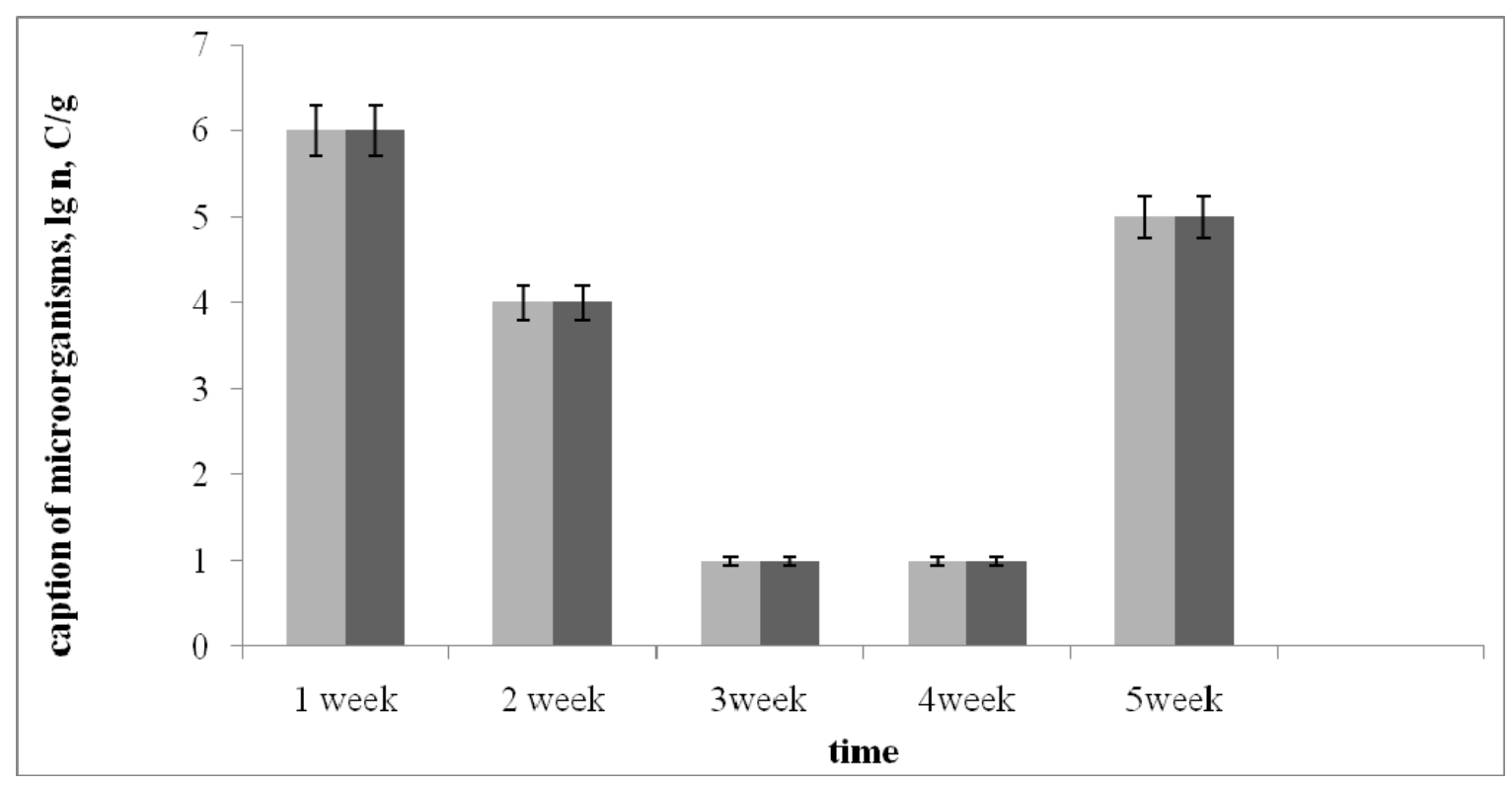

Figure 1. Restoration of number of microorganisms after volley pollution of the soil oil products

The comparative analysis of a condition of spontaneous microflora on the control and regularly polluted by various fractions oil products of soil showed that the number of the main groups heterotrophes makes $58 \%$, the spore-forming microorganisms $-68 \%$ of the number of microorganisms on control sites that is explained by toxic effect of oil products on activity of microrganisms. Microbiological inspection of the petropolluted territories showed that in soil samples as a part of microflora bacteria which number reaches $40 \pm 0.2 \times 10^{6} \mathrm{C} / \mathrm{g}$ prevail. When determining a share the hydrocarbon - oxidizing microorganisms (HOM) in the general structure of microflora of the soil it is established that about $30 \%$ of microorganisms are capable to use oil hydrocarbons as the only source of carbon and energy.

However entering into the petropolluted soil of HOM isn't the only component of technology of recultivation. The spontaneous microflora of the soil at oil pollution is suppressed for two reasons: owing to degradation of oxygen because of obstruction of interstices of soil oil and sharp increase of a ratio of $\mathrm{C}: \mathrm{N}$ in the soil owing to what there comes nitric starvation of microorganisms. These limiting factors are eliminated with agrotechnical receptions: loosening of the soil (plowing) and introduction of nitrogen-phosphorus fertilizers.

On a site 2 agrotechnical works (loosening, introduction of the sawdust impregnated with ammophos solution) without additional introduction of HOM where dynamics of number of microorganisms was traced within 1,5 months were carried out. During supervision under the influence of agrotechnical actions total number of heterotrophes grew three times, and HOM by 9 times (Figure 2). 


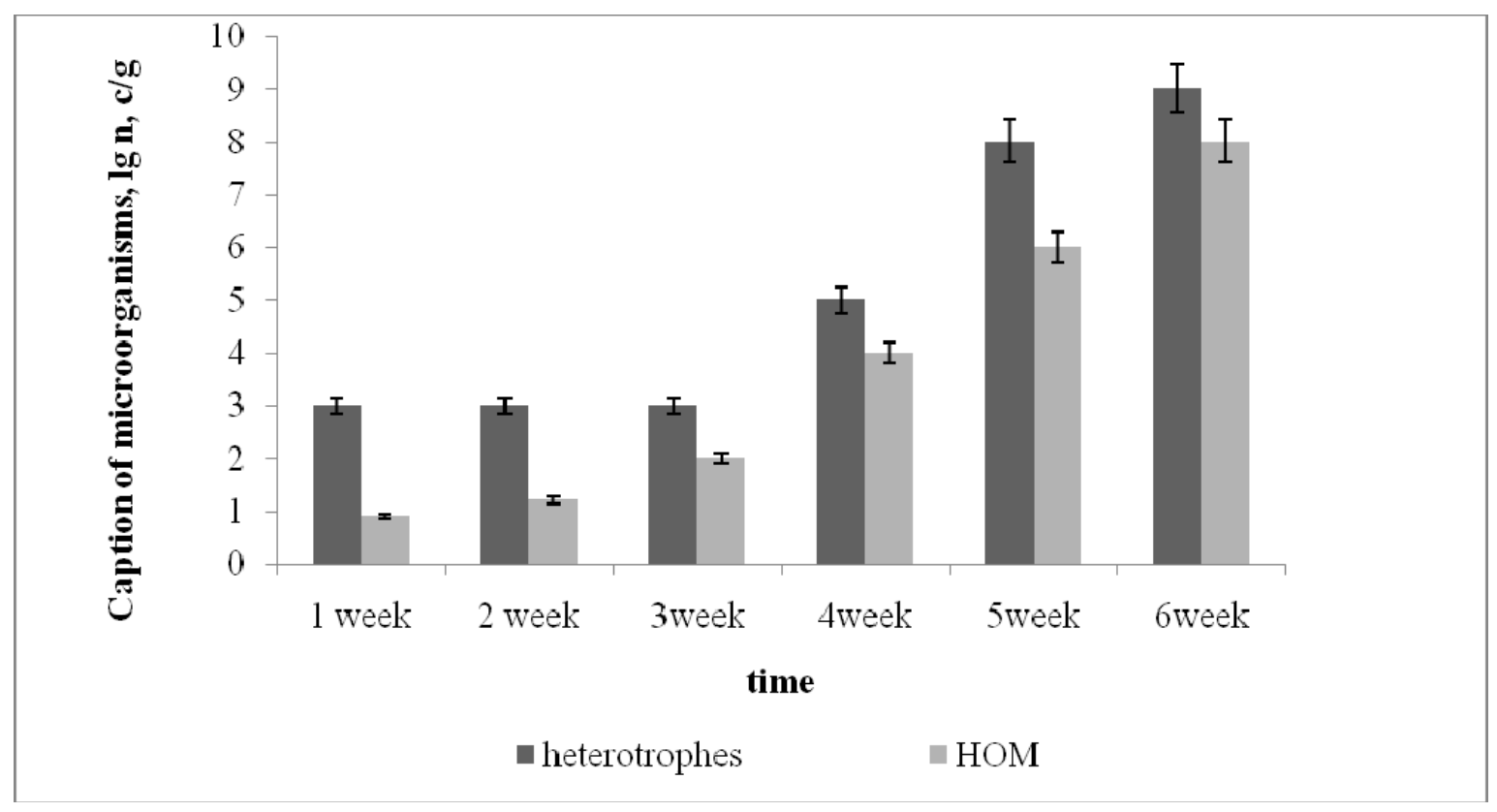

Figure 2. Influence of agrotechnical receptions on dynamics of heterotrophes microflora

The comparative assessment of a condition of the cleared soils of all sites on the horizons showed that initial soils according to the contents in their horizons of oil products are extremely non-uniform. It is caused by that oil products, getting to the soil, are gradually washed away from the top horizons in deeper layers. Possibly, for this reason in the lower layers of earth $(10-45 \mathrm{~cm})$ was much more oil products, than in a blanket. Loosening of the soil on a site with the small content of oil products led to movement of the lower more polluted part of the soil horizons on a surface therefore the amount of oil products in a blanket increased to $1.50 \pm 0.25 \%$. When entering into the plowed soil of HOM biomass and biogenous feed it was noted intensive weeding not only in blankets $(0-10 \mathrm{~cm})$, but also in deeper layer $(10-30 \mathrm{~cm})$. Visually, after bioremediation of the petropolluted soils of site 2 the following changes are noted: right after introduction of biomass of microorganisms the processed soil becomes more dark because of high concentration of the oil products lifted from the lower horizons however for 6-8 days after loosening and introduction of biogenous feed color of the soil changes towards clarification. The soil accepts fine-grained structure, the smell of oil products decreases to a total disappearance.

In the countries of a temperate climate when planning remediation works try to begin work as spring-summer that at warm, rainy weather there passed the mineralization of hydrocarbons in the soil. For arid territories of Kazakhstan as the limiting factor the lack of moisture of the soil therefore for the purpose of economy of water resources the beginning of bioremediation needs to be dated for fall can act to use autumn and spring moistening of the soil for mineralization activity of soil microflora. But between fall and there is a winter period with its low temperatures therefore it is important to know in the spring how winter cooling of the soil will affect microbiological processes in the soil. Low temperatures influence not only the speed of biodegradation of hydrocarbons microorganisms and structure of microbic community, but also the physical nature and a chemical composition of oil. At low temperatures viscosity of oil increases, evaporation of toxic alkanes decreases, their solubility increases in water, the beginning of biodegradation thereby is late. Continuous supervision over a condition of microflora in the soil showed that at fall of temperature during the period from November to February the number of microorganisms in the petropolluted soil decreases to $0-5$ degrees by 6 times that is much lower than summer indicators in the humidified soil. Introduction of HOM biomass allowed to lift a caption of microorganisms, however the speed of a metabolism of bacteria it was rather low.

Along with supervision over the number of microorganisms, we carried out the accounting of amount of oil products in the soil to the period from October to May. In the soil of sites poorly and moderately polluted by oil during the autumn and winter period there is no reduction of amount of oil products (Figure 3). But since March with approach of a warm season the curve of the content of oil products decreases, reaching a minimum in May. 


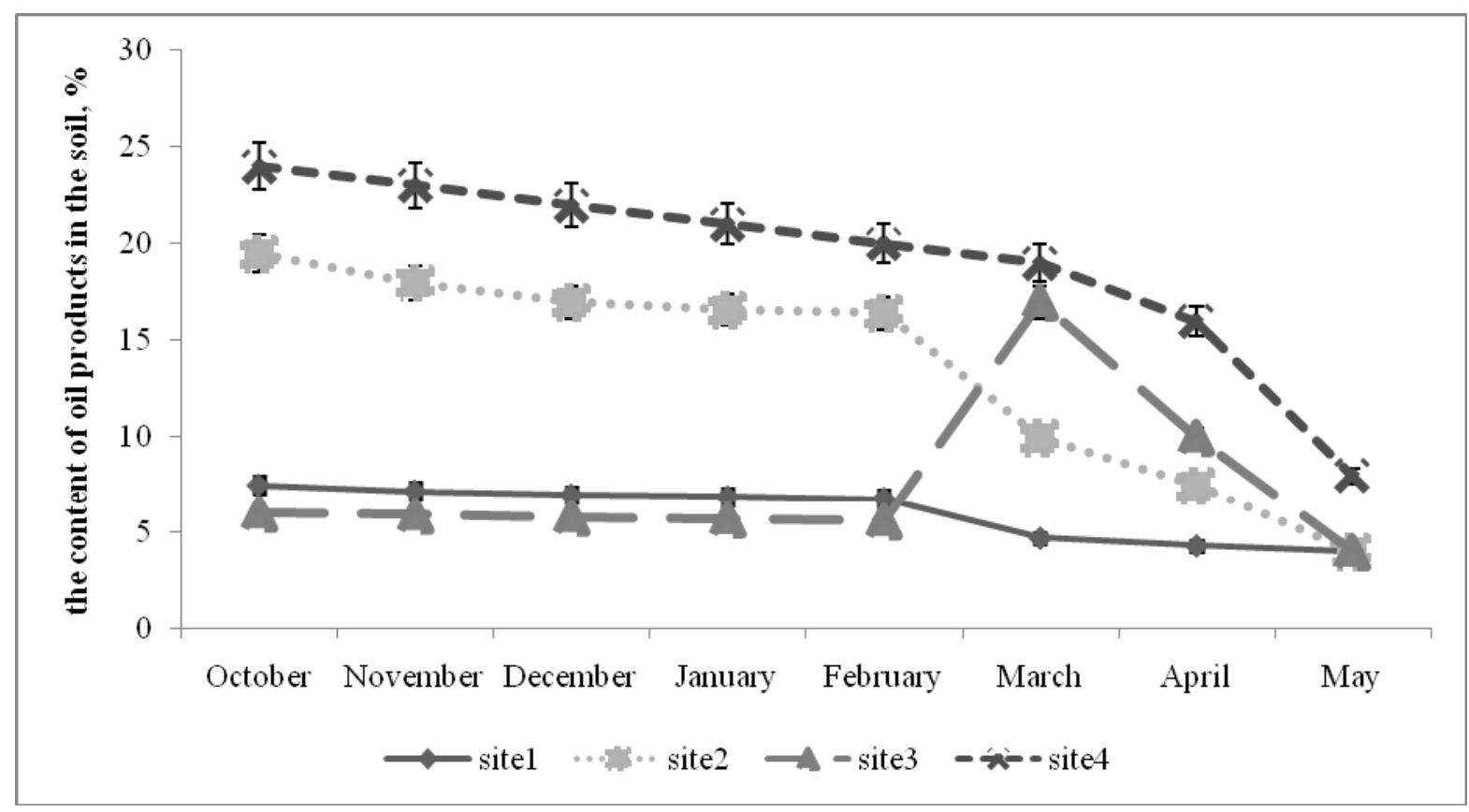

A

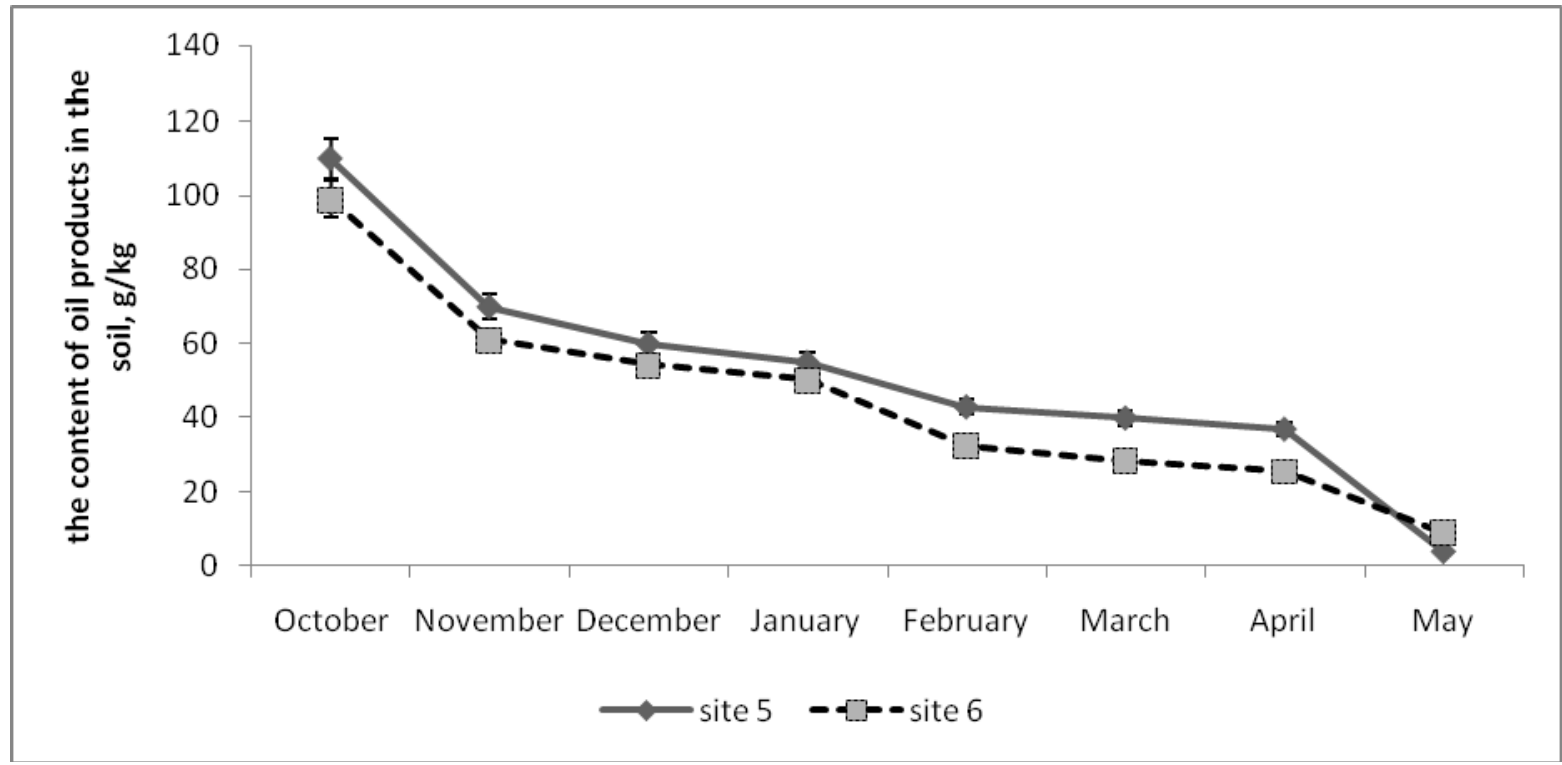

B

Figure 3. Dynamics of decrease in concentration of oil products in soils of skilled sites: A-sites 1-4, B-sites 5,6

\section{Discussion}

In the south of Kazakhstan with temperature increase of air and decrease in an amount of precipitation in summertime there are difficulties with carrying out the bioremediation as the soil dries up and microbiological activity in the soil fades. Therefore development of technology of recultivation of the petropolluted soils in the conditions of arid climate has to include search of optimum time and conditions for activity hydrocarbon oxidizing microorganisms in the soil. The fall when rains, and spring when the soil damp and it starts being warmed begin can be such time in the conditions of the Southern Kazakhstan.

When carrying out bioremediation during the summer period, because of decrease in an amount of precipitation and temperature increase of air there was a difficulty with timely watering of the processed sites. In this regard, the decision to postpone the beginning of terms the bioremediation to the autumn period when the volume of an amount of precipitation starts increasing considerably was made. As a result of the made observations it was 
established that, intensity of process of bioremediation of the petropolluted soil with fall of temperature to $0+50 \mathrm{C}$ decreases. However with temperature increase of air and the soil, process of weeding on sites where the immobilized biomass of bacteria was brought in October, went more intensively in comparison with territories where works began in March. Early-spring loosening, except aerating, bore also the moisture detaining function. As a result of the held events, when carrying out bioremediation water was applied only at the initial stages when the HOM was augmented. For all remained period natural moistening at the expense of rainfall was used. Rather the best exponents of cleaning of sites with the oxidizing microorganisms brought in the fall hydrocarbon: earlier terms of the beginning of activization of HOM, high speed of biodegradation of hydrocarbons of oil probably it is possible to explain with adaptation hydrocarbon of the oxidizing microorganisms to new living conditions, augmented and spontaneous HOM take a launching site that from the beginning of warming to start breeding and consuming hydrocarbons. In this regard, the beginning of bioremediation during the autumn period will allow to increase considerably efficiency of process of cleaning of soils of oil products, and in the conditions of aridity of the region to reduce consumption of water resources.

\section{Conclusion}

In summary, found that the proliferation of microorganisms in the soil depends, not only on the concentration of oil and oil products, but also on the soil conditions: humidity, aeration. Recommended, the start of bioremediation works intended to coincide with autumn term enables to achieve significant reduction of water consumption that is, especially, the matter of current concern in the regions with arid climate.

\section{Acknowledgements}

We would like to thank the Director of the Department of Labour Protection and Ecology LLP"PetroKazakhstan Oil Products" Mr. Emberdiev Amanali and leading specialist of Nature Protection Manapova Nazipa for facilitating the research.

\section{References}

Ayotamuno, J. (2009). Biostimulation supplemented with phytoremediationin the reclamation of a petroleum

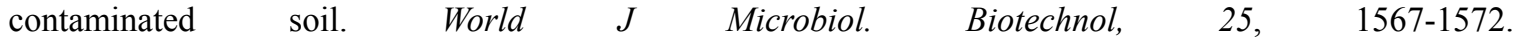
http://dx.doi.org/10.1007/s11274-009-0045-z

Bouyocos, G. H. (1951). A recalibration of the hydrometer for making mechanical analysis of soils. Agron. J., 43, 434-438. http://dx.doi.org/10.2134/agronj1951.00021962004300090005x

Dzondo-Gadet M., Nzikou J. M., \& Matouba, E. (2005). Characterisation and nutritional interest of safou pulp oil. Process Biochem, 40, 307-312. http://dx.doi.org/10.1016/j.procbio.2004.01.003

Jiang, C., et al. (2001). An offsite petroleum contaminated soil bioremediation technology: soil composting in window. Chin J Appl Ecol., 2, 279-282.

Kaplan, C. W., \& Kitts C. L. (2004). Bacterial succession in a petroleum land treatment unit. Appl. Environ. Microbiol, 70(3), 1777. http://dx.doi.org/10.1128/AEM.70.3.1777-1786.2004

Keil, D., Meyer, A., Berner, D., Poll, C., Schtzenmeister, A., Piepho, H. P., ... Marhan, S. (2011). Influence of land-use intensity on the spatial distribution of N-cycling microorganisms in grassland soils. FEMS Microbiol. Ecol., 77, 95-106. http://dx.doi.org/10.1111/j.1574-6941.2011.01091.x

Larter, S. R., Adams, J. J., Gates, I. D., Bennett, B., \& Huang, H. (2008). The origin, prediction and Impact of oil viscosity heterogeneity on the production characteristics of tar sand and heavy-oil reservoirs. Journal of Canadian Petroleum Technology, 47, 52-61. http://dx.doi.org/10.2118/08-01-52

Lazar, I., Dobrota, S., \& Voicu, A. (1999). Microbial degradation of waste hydrocarbonsin oily sludge from some Romanian oil fields. J Petroleum Sci. Eng, 22, 151-160. http://dx.doi.org/10.1016/S0920-4105(98)00064-3

Margesin, R., Zimmerba, uer A., \& Schinner, F. (2000). The impact of hydrocarbon remediation (diesel oil and polycyclicaromatic hydrocarbons) on enzyme activities and microbial properties of soil. Acta Biotechnol, 20,313. http://dx.doi.org/10.1002/abio.370200312

Marn, S., \& Khodijah, T. (2004). Bioremediation of coastal areas 5 years after the Nakhodka oil spill in the Sea of Japan: isolation and characterization of hydrocarbon-degrading bacteria. Environ Int., 7, 911-922.

Mishra, S., Jyot, J., Kuhad, R. C., \& Banwari, Lal. (2001). Evaluation of inoculum addition to stimulate in situ bioremediation of oily-sludge-contaminated soil. Appl. Environ. Microbiol, 67(4), 1675-1681. http://dx.doi.org/10.1128/AEM.67.4.1675-1681.2001

Olsen, S. R., Cole, C. V., Watnab, F. S., \& Decan, L. A. (1954). Estimation of available phosphorous in soil by 
extra action with sodium bicarbonate U.S. Department of Agric., pp: 939.

Panicker, G., Aislabie, J., Saul, D., \& Bej, A. K. (2002). Cold tolerance of Pseudomonas sp. 30-3 isolated from oil-contaminated soil, Antarctica. Polar Biol., 25, 5-11. http://dx.doi.org/10.1007/s003000100304

Sankaram, A. (1996). A Laboratory manual for agricultural chemistry, Asia publishing house, New Dehli, 340.

Wan, N., Hwang, E. Y., \& Park, J. S. (2002). Bioremediation of diesel contaminated soil with composting. Environ Pollut., 8, 23-31.

Wyszkowska J., Kuchar ski J. (2000) Biochemical properties of soil contaminated by petrol. Pol. J. Environ. St. $9(6), 479$.

\section{Copyrights}

Copyright for this article is retained by the author(s), with first publication rights granted to the journal.

This is an open-access article distributed under the terms and conditions of the Creative Commons Attribution license (http://creativecommons.org/licenses/by/3.0/). 